\title{
BioéthiqueOnline
}

\section{Non-Invasive Prenatal Testing: Review of Ethical, Legal and Social Implications}

\section{Hazar Haidar, Charles Dupras et Vardit Ravitsky}

Volume 5, 2016

URI : https://id.erudit.org/iderudit/1044264ar

DOI : https://doi.org/10.7202/1044264ar

Aller au sommaire du numéro

Éditeur(s)

BioéthiqueOnline

ISSN

1923-2799 (numérique)

Découvrir la revue

\section{Citer cet article}

Haidar, H., Dupras, C. \& Ravitsky, V. (2016). Non-Invasive Prenatal Testing: Review of Ethical, Legal and Social Implications. BioéthiqueOnline, 5. https://doi.org/10.7202/1044264ar
Résumé de l'article

Le test prénatal non-invasif (TPNI) reposant sur l'utilisation de l'ADN foetal libre (cffDNA) dans le sang maternel a été introduit dans la pratique clinique dans de nombreux pays, incluant le Canada. Ce test peut être effectué tôt durant la grossesse pour détecter le syndrome de Down ainsi que d'autres conditions. Bien que le TPNI promette de nombreux avantages, il comporte aussi des enjeux éthiques, légaux et sociaux (ELS). Cet article recense les préoccupations qui se trouvent actuellement dans la littérature sur les enjeux ELS du TPNI. Nous faisons quatre observations. Tout d'abord, le TPNI semble exacerber certaines des préoccupations existantes et soulevées par d'autres tests prénataux (l'amniocentèse et le dépistage du sérum maternel), telles que les menaces à l'autonomie reproductive des femmes et la discrimination et la stigmatisation potentielles des personnes handicapées et de leurs familles. Cela peut être attribué à la probable mise en oeuvre en grande échelle et par la routinisation à venir du TPNI. Deuxièmement, la distinction entre le TPNI comme un test de dépistage (tel qu'il est actuellement recommandé) et comme un test de diagnostic (potentiellement dans le futur), présente certaines implications sur la discussion des enjeux ELS. Troisièmement, nous avons observé un changement progressif dans la littérature. Celle-ci était à l'origine composée d'analyses essentiellement conceptuelles, mais recense maintenant un nombre croissant d'études empiriques. Cela démontre la contribution des approches de la bioéthique empirique alors que la technologie est en cours d'implantation au sein de la pratique clinique. Enfin, nous avons constaté un intérêt croissant pour les questions de justice et d'équité en matière d'accès au TPNI dans la mesure où le test devient implanté à une échelle plus large.
Ce document est protégé par la loi sur le droit d'auteur. L'utilisation des services d'Érudit (y compris la reproduction) est assujettie à sa politique d'utilisation que vous pouvez consulter en ligne.

https://apropos.erudit.org/fr/usagers/politique-dutilisation/ 


\title{
Non-Invasive Prenatal Testing: Review of Ethical, Legal and Social Implications
}

\author{
ARTICLE (RÉVISION PAR LES PAIRS / PEER-REVIEWED) \\ Hazar Haidar ${ }^{1}$, Charles Dupras ${ }^{1}$, Vardit Ravitsky ${ }^{1}$
}

Reçu/Received: 5 Apr 2015

Publié/Published: 26 Feb 2016

Éditeur/Editor: Renaud Boulanger

Évaluateurs externes/Peer-Reviewers: Zuzana Deans \& Shawn Winsor

2016 H Haidar, C Dupras, V Ravitsky, Creative Commons Attribution 4.0 International License

\section{Résumé}

Le test prénatal non-invasif (TPNI) reposant sur l'utilisation de l'ADN fœtal libre (cffDNA) dans le sang maternel a été introduit dans la pratique clinique dans de nombreux pays, incluant le Canada. Ce test peut être effectué tôt durant la grossesse pour détecter le syndrome de Down ainsi que d'autres conditions. Bien que le TPNI promette de nombreux avantages, il comporte aussi des enjeux éthiques, légaux et sociaux (ELS). Cet article recense les préoccupations qui se trouvent actuellement dans la littérature sur les enjeux ELS du TPNI. Nous faisons quatre observations. Tout d'abord, le TPNI semble exacerber certaines des préoccupations existantes et soulevées par d'autres tests prénataux (l'amniocentèse et le dépistage du sérum maternel), telles que les menaces à l'autonomie reproductive des femmes et la discrimination et la stigmatisation potentielles des personnes handicapées et de leurs familles. Cela peut être attribué à la probable mise en œuvre en grande échelle et par la routinisation à venir du TPNI. Deuxièmement, la distinction entre le TPNI comme un test de dépistage (tel qu'il est actuellement recommandé) et comme un test de diagnostic (potentiellement dans le futur), présente certaines implications sur la discussion des enjeux ELS. Troisièmement, nous avons observé un changement progressif dans la littérature. Celle-ci était à l'origine composée d'analyses essentiellement conceptuelles, mais recense maintenant un nombre croissant d'études empiriques. Cela démontre la contribution des approches de la bioéthique empirique alors que la technologie est en cours d'implantation au sein de la pratique clinique. Enfin, nous avons constaté un intérêt croissant pour les questions de justice et d'équité en matière d'accès au TPNI dans la mesure où le test devient implanté à une échelle plus large.

\section{Mots clés}

test prénatal non-invasif (TPNI), enjeux éthiques, légaux et sociaux (ELS), autonomie reproductive, consentement éclairé, interruption de grossesse, discrimination, attitudes eugéniques, implantation du TPNI

\section{Abstract}

Non-invasive prenatal testing (NIPT) using cell-free fetal DNA (cffDNA) from maternal blood has recently entered clinical practice in many countries, including Canada. This test can be performed early during pregnancy to detect Down syndrome and other conditions. While NIPT promises numerous benefits, it also has challenging ethical, legal and social implications (ELSI). This paper reviews concerns currently found in the literature on the ELSI of NIPT. We make four observations. First, NIPT seems to exacerbate some of the already existing concerns raised by other prenatal tests (amniocentesis and maternal serum screening) such as threats to women's reproductive autonomy and the potential for discrimination and stigmatization of disabled individuals and their families. This may be due to the likely upcoming large scale implementation and routinization of NIPT. Second, the distinction between NIPT as a screening test (as it is currently recommended) and as a diagnostic test (potentially in the future), has certain implications for the ELSI discussion. Third, we observed a progressive shift in the literature from initially including mostly conceptual analysis to an increasing number of empirical studies. This demonstrates the contribution of empirical bioethics approaches as the technology is being implemented into clinical use. Finally, we noted an increasing interest in equity and justice concerns regarding access to NIPT as it becomes more widely implemented.

\section{Keywords}

non-invasive prenatal testing (NIPT), ethical legal and social issues (ELSI), reproductive autonomy, informed consent, pregnancy termination, discrimination, eugenic attitudes, NIPT implementation 


\section{Exonération}

Les évaluations des examinateurs externes sont prises en considération de façon sérieuse par les éditeurs et les auteurs dans la préparation des manuscrits pour publication. Toutefois, être nommé comme examinateur n'indique pas nécessairement l'approbation du manuscrit par cet examinateur. Les éditeurs de BioéthiqueOnline assument la responsabilité entière pour l'acceptation finale et la publication d'un article.

\section{Disclaimer}

Reviewer evaluations are given serious consideration by the editors and authors in the preparation of manuscripts for publication. Nonetheless, being named as a reviewer does not necessarily denote approval of a manuscript by the reviewer; the editors of BioéthiqueOnline take full responsibility for final acceptance and publication of an article.

Affiliations des auteurs / Author Affiliations

${ }^{1}$ Department of Social and Preventive Medicine, School of Public Health, Université de Montréal, Montreal, Canada

\section{Correspondance / Correspondence}

Hazar Haidar, hazar.haidar@umontreal.ca

\section{Remerciements}

Ce travail a été effectué dans le cadre du projet de recherche PEGASUS (Génomique personnalisée pour le dépistage prénatal de l'aneuploïdie utilisant le sang maternel), financé par Génome Canada, Génome Québec et les Instituts Canadiens de Recherche en Santé du Canada (IRSC). Les auteurs tiennent à remercier Shawn Winsor et Zuzana Deans, les évaluateurs de cet article, pour leurs commentaires opportuns et très utiles.

\section{Conflit d'intérêts}

Hazar Haidar est éditrice et Charles Dupras est éditeur de section de BioéthiqueOnline. Vardit Ravitsky est professeure agrégée aux programmes de bioéthique à l'École de santé publique de l'Université de Montréal, et est une collègue de l'éditeur-en-chef de la revue, Bryn Williams-Jones. Les auteurs et l'éditeur-en-chef n'ont participé à aucune partie du processus d'évaluation ou d'examen par les pairs. Ce processus a été dirigé par un membre de l'exécutif de la revue, Renaud Boulanger.

\section{Acknowledgements}

This work was completed as part of the PEGASUS (PErsonalized Genomics for prenatal Aneuploidy Screening USing maternal blood) research project, funded by Genome Canada, Genome Quebec and the Canadian Institutes for Health Research (CIHR). The authors would like to thank Shawn Winsor and Zuzana Deans, the reviewers of this paper, for their insightful and very helpful comments.

\section{Conflicts of Interest}

Hazar Haidar is an editor and Charles Dupras is a Section editor at BioéthiqueOnline. Vardit Ravitsky is an Associate professor in the Bioethics Program at the School of Public Health of the Université de Montréal, and a colleague of Bryn Williams-Jones, the Editor-in-chief of the journal. The authors and the Editor-in-chief were not involved in any part of the evaluation or peer-review process, which was managed by a member of the journal's Executive, Renaud Boulanger.

\section{Introduction}

Non-Invasive Prenatal Testing (NIPT) is a novel technology that allows the analysis of cell-free fetal DNA (cffDNA) obtained from maternal plasma [1]. cffDNA can be detected as early as 7 weeks gestation and its analysis - as early as 9 weeks - requires a simple blood draw from the pregnant woman. NIPT is considered more reliable than current screening tests. It has better sensitivity (true positive rate) and specificity (true negative rate) for the detection of aneuploidies (i.e., greater than $99 \%$ for trisomy 21 and about $97 \%$ for trisomy 13 and 18) and it produces fewer false positive results $[2,3]$. At the same time, it is not yet sufficiently reliable to be considered as a diagnostic test. For this reason, NIPT cannot yet fully replace diagnostic tests such as amniocentesis and chorionic villus sampling (CVS) [4], which are still required for validating a positive NIPT result.

NIPT is currently being introduced into clinical practice in over 60 countries around the world [5]. It is commercially available for the detection of trisomy 13,16, 18, 21 and 22, for sex chromosome abnormalities, fetal sex, RhD status, and specific microdeletions ${ }^{1}$ [7]. MaterniT21 was the first commercially available test for trisomy 21 detection launched in 2011 by U.S.-based Sequenom, Inc., followed since by others companies such as Ariosa Diagnostics, Natera and Verinata Health [8].

\footnotetext{
${ }^{1}$ Microdeletion is a chromosomal deletion [6] spanning several genes that is too small to be detected under the microscope using conventional cytogenetic methods.
} 
Professional societies recommend its use as a second-tier screening test only for pregnancies that are identified as having an increased risk of fetal aneuploidies based on their initial screening test's results (Maternal Serum Screening or MSS) [9-11]. A clinical study partially sponsored by Sequenom Inc. for NIPT validation in the low-risk population showed that its use for aneuploidy screening is "likely to perform analytically as well in different risk groups of pregnant women" [12]. Other studies have suggested that it could be used as a diagnostic test for single gene disorders [13] and that it holds potential for fetal whole genome sequencing (FWGS) [14,15]. One of the latter studies related to FWGS was partly funded by Sequenom, Inc. while the other includes an author who acts as a consultant for Ariosa Diagnostics. The fact that NIPT research and development is being sponsored and funded by industry creates an inherent conflict of interest that might bias research outcomes. For instance, data publication and interpretation related to NIPT could emphasize the sensitivity and specificity of the test while underrepresenting its limits, such as its positive predictive value or the need to confirm a positive result with a diagnostic test [16]. These financial conflicts of interest can compromise the integrity of research related to NIPT and therefore influence a patient's decisionmaking regarding the test. Moreover, some companies providing their own genetic counselling services are being criticized for paying genetic counsellors who are advising patients on whether to undergo testing [17]. Such situation raises concerns about the neutrality of counselling and the patient's informed decision.

With commercialization and progressing clinical implementation of NIPT, we have noticed that the academic literature exploring the ethical, legal and social implications (ELSI) of NIPT has increased significantly (Figure 1).

\section{Figure 1: Number of identified peer-reviewed papers addressing ELSI of NIPT published every year between 2007 and 2015}

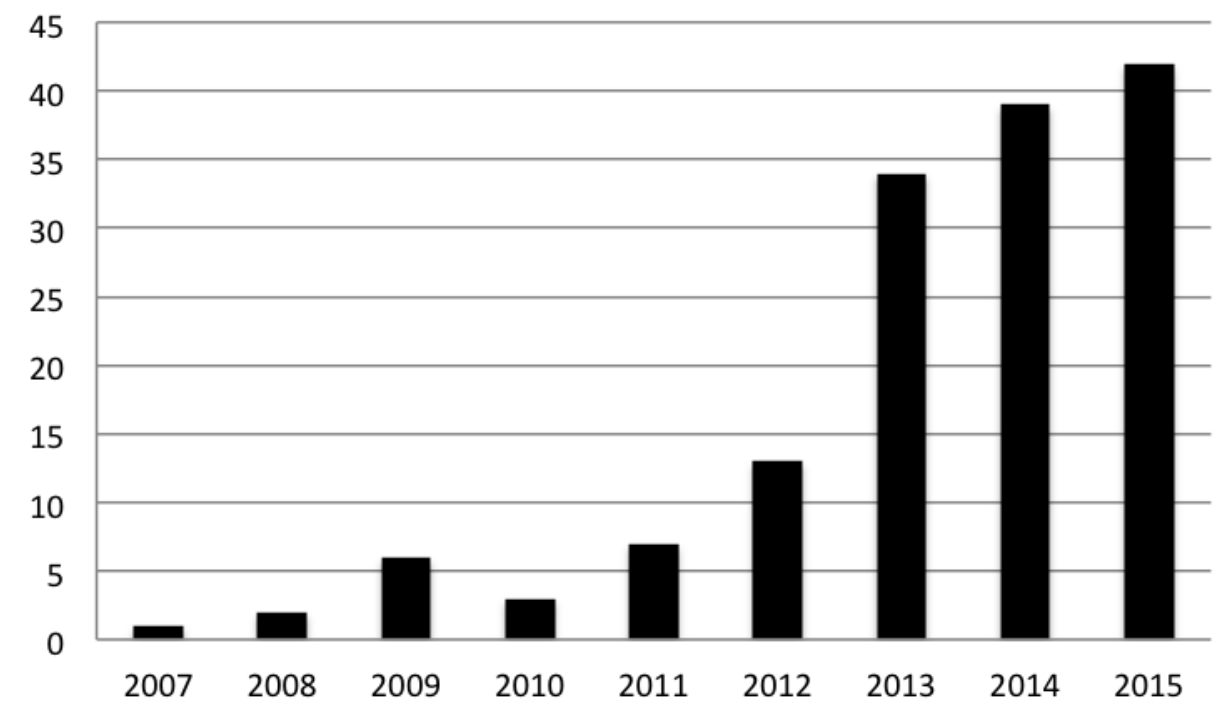

NIPT's implications at individual and societal levels were reported through a diversity of publications such as empirical studies (qualitative and quantitative), conceptual analysis, and professional guidelines. Authors from multiple backgrounds (e.g., physicians, genetic counsellors, gynecologists, social scientists, disability rights and patient advocates) have discussed the implications of NIPT for women and families, healthcare professionals, the healthcare system and society [18-28]. Questions have been raised and discussed regarding the ways in which NIPT implementation should be handled so as to be ethically sound and socially acceptable. 
This paper reviews the literature addressing the ELSIs associated with NIPT and presents benefits and concerns found in this literature. These ELSIs are associated with three commonly discussed features of NIPT: its capacity to provide genetic information early in the pregnancy (timing), the simplicity of the procedure, which requires only a blood draw (ease), and the absence of an increased risk of miscarriage (safety ${ }^{2}$ ). It is crucial to note, however, that the implications of these three features - timing, ease and safety - are discussed in two different contexts. In the earlier days of NIPT, following the first success in detecting and analyzing cffDNA (2007-2011), many believed it would be introduced into clinical use as a diagnostic test. It was therefore compared to current diagnostic tests and heralded as 'safe' and allowing earlier diagnosis [29,30].

Nevertheless, once data emerged showing that NIPT is not (yet) reliable enough to replace diagnostic tests, it was gradually integrated into clinical use as a screening test [2]. This change in its 'clinical status' was reflected by a change in the ELSI debate, as explained below. Although the nascent ELSI literature regarding the use of NIPT as a screening test discusses similar benefits and concerns as those related to its use as a diagnostic test [31], there are still significant differences. For example, when a diagnostic test is required following NIPT as a screening test, the benefit of 'earlier testing' is diminished $[7,20]$ but the concern regarding NIPT becoming a one-step test is mitigated [7].

References in this review to the three features of NIPT (ease, safety, timing) thus relate both to the early ELSI literature that considered it as diagnostic test and to the more recent literature that considers it as a screening test, with appropriate specifications where necessary. The concerns that relate specifically to NIPT as a diagnostic test are still relevant, since it is likely that in the future NIPT will become sufficiently reliable to be used for diagnosis.

\section{Methods}

\section{Objective}

This paper aims to review benefits and concerns currently found in the literature on the ELSI of NIPT based on a critical interpretive literature review [32]. This review is timely and can serve as a foundation for researchers who wish to inform and contextualize their empirical and conceptual work regarding NIPT.

\section{Search methods}

We searched three relevant databases: CINAHL, Medline and psycINFO. We also hand-searched for further publications by first authors of well-cited papers, as well as highly relevant journals such as: Prenatal Diagnosis, American Journal of Obstetrics and Gynecology, European Journal of Human Genetics and Public Health Genomics. The search strategy was facilitated by using variant terminology for the same keyword (e.g., cell free fetal DNA test and non-invasive prenatal test) and by different combinations of those keywords. The combination of searched terms used was: ('noninvasive' or 'non invasive') or/and ('cell free fetal DNA') or/and ('prenatal' or 'antenatal') and ('testing' or 'screening') or/and ('ethics' or 'social' or 'legal').

\section{Inclusion criteria and analysis}

All abstracts were reviewed and the papers were judged eligible for inclusion if they focused on ethical and/or social and/or legal implications of NIPT and if they were published between January 2007 and April 2015. Reported studies could be conducted in any country, but had to be published in English or French in peer-reviewed journals. One researcher, H.H., performed the search and the review: she read the full text of each article, evaluated the relevance of retrieved papers, identified recurrent

\footnotetext{
${ }^{2}$ In this paper, the terms 'safety' or 'safe' are used to underscore the fact that NIPT carries no increased risk of miscarriage. By using these terms we do not imply that NIPT is free of any type of risk (such as increased anxiety) or that it cannot have undesirable consequences at various levels.
} 
arguments related to the ELSIs of NIPT and grouped them under key themes. Two other researchers, C.D. and V.R., read some of the papers and then all three (H.H., C.D. and V.R.) validated the coding of the content by comparing and discussing the grouping of themes and their classification. Discrepancies between different coding were discussed until a consensus was reached.

The structure of the review reflects the benefits and concerns observed in the literature, grouped under four major themes: NIPT and reproductive autonomy; the routinization of NIPT and its impact on decision-making and informed consent; social impact; and the implementation of NIPT.

\section{Findings}

\section{NIPT and reproductive autonomy}

In allowing easier, safer and earlier testing, NIPT has often been portrayed as carrying great benefits and as promoting reproductive autonomy. In the early papers that discussed it as a diagnostic test, it was suggested that access to genetic information in the first trimester would allow women and their families more time to make a decision regarding their pregnancy management: to prepare for the birth of a child with special needs or to make a decision regarding termination of pregnancy [33]. For those who decided to terminate, NIPT would allow an earlier termination, making it medically safer and allowing it to occur when maternal-fetal attachment might be less established and when the pregnancy was not yet socially visible $[27,34]$.

While the earlier timing of NIPT as a diagnostic test was mostly heralded as a great benefit, some authors pointed out that it might also have adverse effects by increasing the burden of choice imposed on women and so generate additional anxiety [25, 33]. Pregnancies involving fetuses with genetic abnormalities sometimes end in spontaneous abortion. While some women would prefer to avoid the trauma of a miscarriage, even if doing so means requesting an abortion, for others, the earlier testing by NIPT could transform the 'natural phenomenon' of spontaneous abortion, over which women have no control, into the result of a deliberate and voluntary choice [35]. For some women, earlier testing with NIPT would therefore increase the pressure on them to make excruciating decisions that were previously unnecessary, potentially turning the expanded 'reproductive autonomy' offered by the test into a heavy moral burden [36].

As the development of NIPT technology progressed it became clear that NIPT should be considered a screening test and that a positive result requires confirmation through invasive testing, which limited the discussion of benefits on those receiving a negative result. NIPT's main advantage as a screening test was thus seen as its higher reliability in comparison to previous screening tests. Women who screen as high-risk can turn to NIPT rather than proceed straight to diagnostic testing. For most of these women, a negative NIPT result would be reassuring enough to allow them to refrain from further invasive testing and its associated risks $[20,27]$. Thus, by providing a new option, NIPT was seen as promoting reproductive autonomy by allowing women access to more reliable results without an increased risk of miscarriage.

\section{The routinization of NIPT: Impact on decision-making and informed consent}

The early papers that discussed NIPT as a diagnostic test raised concerns that the test would be offered to all pregnant women as a routine part of pregnancy care, and would thus be perceived by women as "just another blood test", without a full understanding of its meaning and potential impact [7]. Since routinization is associated with lower rates of informed choice [37], it was feared that decision-making would be undermined and that pressure to test would increase [27,38]. In the context of invasive testing (e.g., amniocentesis), the decision not to test could be 'justified' by the wish to avoid an increased risk of miscarriage. By removing this 'socially acceptable' justification, it was 
argued that NIPT significantly modified the decision-making context and might increase the pressure on women by leaving them with "no reasonable argument" for rejecting the test $[27,33,34,36,39]$.

The potential routinization of NIPT could erode informed consent procedures [28,37,40-42]. Empirical studies have shown that due to the safety of the test, the consent process for NIPT (including written consent) is viewed, overall, as less important than for invasive testing [28,43]. However, Silcock and colleagues' study reveals that women considered a greater need for written consent $(87 \%$ of women believed written consent is required for NIPT compared with $97 \%$ for invasive diagnostic tests) than health professionals $(78 \%$ of health professionals believed written consent is required for NIPT compared with $97 \%$ for invasive diagnostic tests). The authors noted that "it was difficult to know if they [women] were stating what they thought was expected of them, or saw written consent as an important element of decision-making" and thus they called for exploratory research in this area. This discrepancy is also a potential source of ethical concern given the unequal power relationship between patients and health professionals regarding the information that should be shared with women to ensure their consent is informed. For example, while women might consider a written consent as a tool offering more information about the test, professionals might view it as a legal protection ensuring the woman's documented agreement or disagreement to take the test [28].

The perception of written consent as less important for NIPT than for invasive testing may in the long term undermine informed decision-making and reproductive autonomy because women, their partners and health professionals may not give as much thought to the potential implications of a safe blood test compared to an invasive test. As Silcock and colleagues recently suggested: "written informed consent may help the test stand out from routine blood tests and encourage fuller discussion of the implications" [28].

NIPT was also described as posing new challenges related to genetic counselling. It was argued that if NIPT were to be offered to all pregnant women (high and average risks), the counselling demand could not be met with current limited resources $[5,44]$ and that such demand would be prohibitively burdensome for a public healthcare system operating within budget limits [7]. On the other hand, it is suggested that NIPT will facilitate pre-test counselling discussion since it would not require the complex explanation of miscarriage risk [34] and understanding probabilities [36]. Some expressed concerns that a simple blood test, if performed on the same day as pre-test counselling, would only allow a short time frame for reflection and might result in rushed and uninformed decisions. It was thus argued that NIPT should be offered and performed on two different days, to allow appropriate pre-test counselling and reflection [45]. However, empirical studies showed that some women prefer to make a decision about NIPT at the same appointment at which it is offered $[27,28]$, leading to a rushed decision-making process that might undermine informed choice [43].

\section{Social impact of NIPT}

The potential high uptake of NIPT $[46,47]$ raised concerns addressed by different authors related to the reasons for which individuals would wish to test and the social impact of such individual decisions [48,49]. The main concerns in this context are the possible lowering of the threshold of testing and the risk of increased stigmatization and discrimination against individuals with disabilities and their families, as well as the resurgence of eugenic social attitudes.

\section{Lowering the threshold of testing and pregnancy termination}

While the invasiveness and risk of miscarriage associated with current diagnostic testing prevent the expansion of its uptake for a wider range of conditions, NIPT's capacity to offer genetic information in a safe and easy manner is anticipated to lower the threshold of testing, i.e., to encourage women to consider prenatal testing as appropriate for less severe conditions and even for non-medical reasons [34,50,51]. It is thus argued that in the future, expanding the scope of NIPT could generate large amounts of information regarding late onset diseases (e.g., Huntington's), predispositions to severe and common diseases (e.g., breast cancer and diabetes), minor abnormalities [52-54], and 
even non-medical information (e.g., paternity) and physical traits (e.g., eye colour). While such an expansion of testing may promote women's and couples' reproductive autonomy by offering access to more information, it also introduces two concerns. First, an avalanche of genetic information that is difficult to interpret and explain, some of it of unknown significance, leading to confusion on the part of couples and health professionals $[21,29]$. Second, in cases where NIPT does not lead to termination of the pregnancy, the extensive genetic information about the fetus can become a threat to the resulting child's privacy. Some have argued that testing purely for information (without any intention to terminate) for a range of conditions - such as adult-onset diseases - would be wrong because it could impede the child's future choices (i.e., "right to an open future"), and also to some extent create harm, since "the child may feel greater anxiety knowing he faces a future with a particular condition" [55].

As a further complication, increased information might ultimately result in an increase in the volume of terminations $[27,56,57]$ as well as its 'trivialization', i.e., termination of pregnancies for minor or unimportant reasons [29,45,58-60]. As mentioned previously, the earlier women have access to diagnostic information, the earlier they can make a decision and proceed to termination when it is medically safer and potentially less psychologically traumatic [27,45,61]. For instance, in cases where NIPT reveals a very high risk of Huntington's disease, women who would not terminate a pregnancy in the second trimester might decide to do so in the first trimester, even if NIPT had not yet been validated as diagnostic [45]. Moreover, the possibility of earlier and safer testing for non-medical traits, such as the sex of the fetus, could lead to an increase in ethically controversial selective abortions $[53,58,62,63]$.

\section{Discrimination, stigmatization and eugenic attitudes}

In the long term, the large-scale implementation of NIPT and its potential validation as a diagnostic test could result in an increase in both the detection of an important number of fetal conditions and in termination rates $[5,63]$, thereby substantially reducing the prevalence of certain conditions in society [64]. While this eventuality carries public health benefits by reducing high costs of care for people with disabilities such as Down Syndrome [24], it is argued that it could also increase the stigmatization of and discrimination against individuals living with these conditions and their families [24,44,65]. For instance, mothers of children with Down syndrome have expressed worries about a decrease in social acceptance of people with Down syndrome and thus a decrease in the investment of resources and support for affected individuals and their families $[22,44,45,66]$. This might also negatively impact research efforts that focus on the development of treatments for conditions such as Down Syndrome [57]. There are concerns that the availability of NIPT would result in social pressure as well as stigmatization of those women who decide to continue an affected pregnancy, because conditions that would be detectable by NIPT would be perceived as "easily avoidable" [27,35].

Lowering the threshold of testing and the trivialization of pregnancy termination might lead to changing expectations about what people "should do" when NIPT reveals genetic abnormalities in the foetus, or even 'socially undesirable' traits [67]. Concerns are therefore expressed about NIPT paving the road to a "quest for a perfect baby", progressively creating new forms of eugenics in society $[68,69]$. Empirical studies show that people are concerned about eugenic behaviours resulting from increased stigmatization and discrimination against disabled people following the large-scale implementation of NIPT [70]. Potential future use of NIPT for fetal whole-genome sequencing (WGS) and the increase in the amount of genetic information obtained from the fetus exacerbate such concerns.

In order to ensure an ethically sound implementation of NIPT - and possibly Non-Invasive Prenatal Diagnosis (NIPD) in the future - and to avoid a slippery slope towards eugenics, it has been suggested that such issues must be discussed in the public arena [60]. Each step towards increased control over human reproduction should be addressed adequately to prevent possible conflicts with social values [65]. However, while concerns regarding a resurgence of eugenic ideas and practices 
are articulated, it is also argued that Western societies already have numerous policies and regulations - for instance, relating to respect of individual choices or the rights of disabled individuals - that can help prevent a radical eugenic drift [67].

\section{The implementation of NIPT}

\section{Legal and regulatory issues related to NIPT implementation}

NIPT technology innovation, quality, cost and availability are all closely linked to patenting and intellectual property issues. Currently, there are hundreds of patents related to cffDNA testing, with some of them already granted and others pending. Since 2011, four companies in the US (Sequenom, Verinata Health, Ariosa and Natera) have been locked in patent litigation [71]. Early in December 2014, Illumina (parent company of Verinata Health) and Sequenom settled their patent and intellectual property dispute and agreed to pool their NIPT patents [72]. While other disputes are ongoing (e.g., Ariosa vs. Sequenom), and might take time to resolve, concerns are raised that one company might secure market monopoly [71]. In such a case, the company that prevails could prevent competitors from developing and providing the test, which may result in an increase in price, in lower availability and access, as well as limited research aimed at developing NIPT technology [73].

The clinical introduction of NIPT has stimulated discussions regarding equity of access, arising both from the commercial/private implementation and its potential public funding. In the absence of public universal coverage, NIPT will be accessible only to those who are able to afford it, exacerbating inequalities in access to the test [5,7] and socioeconomic stratification. Indeed, NIPT could become a 'reproductive strategy' that is available to a privileged portion of the population, allowing certain parents to 'choose' the best genetic characteristics for their children [29]. In a study performed by Yotsumoto and colleagues to assess pregnant women and health professionals' attitudes toward NIPT, pregnant women expressed worries about the possibility of unequal access to NIPT due to its high cost, especially in a context where it would be offered by private companies and not covered by public funding $[62,74]$. The ELSI literature has frequently called for policies that support equity in access to NIPT in various countries [5,75].

\section{The promotion of NIPT by private companies}

The aggressive advertising of NIPT by private companies, as well as its introduction prior to the publication of professional guidelines, created some confusion regarding how to best incorporate NIPT into clinical practice $[8,16]$. For instance, the fact that its imperfect specificity, sensitivity and positive predictive value cannot validate it as diagnostic was arguably minimized when different companies rushed to capture a market share [8]. Consequently, potential benefits for women and families were over-estimated. Moreover, direct-to-consumer (DTC) commercial offer of NIPT is considered by several authors to be a potential threat to an ethical implementation of this test $[7,49,50]$. Health professionals do not recommend this type of marketing for NIPT, arguing that women and couples may not have access to suitable information, counselling and support to guide their decision-making [25,50].

\section{Challenges for NIPT implementation in a public healthcare system}

In several countries (e.g., Canada, UK, France), prenatal screening for fetal abnormalities (e.g., trisomy 21) is offered to pregnant women as part of publicly funded programs. The chief purpose of such programs is to "enable meaningful reproductive choice with regard to parenting or avoiding a child with a serious disorder or disability" [76]. For the time being, NIPT's clinical introduction is left to commercial companies that are offering their test through health professionals without the involvement of governments or public health agencies [7].

However, implementing NIPT into public health programs would raise several challenges related to the availability of budgetary [77,78] and personnel resources [53]. For instance, if and when NIPT is validated for use by all pregnant women (high and average risk), challenges will be introduced regarding the coverage within the available limited budget in order to ensure equity of access [7]. 
Another barrier will be the scarce resources of available health professionals (e.g., genetic counsellors) to meet an increased demand for counselling [5]. The rapid technological advancement and future expansion in scope of the conditions that NIPT can detect may further complicate matters. If NIPT is introduced into a public healthcare system, questions will arise regarding which conditions should be covered, for whom, who should make these decisions and how $[50,79]$.

Cost-benefit analyses must be nuanced because universal accessibility would be costly for a public healthcare system. For instance, the Canadian Agency for Drugs and Technologies in Health (CADTH) released a report reviewing the cost-effectiveness of NIPT in several countries (US, Australia, Canada) and the key findings were that "at the present time, universal screening with NIPT appears to increase costs substantially and is unlikely to be feasible. However, the use of NIPT in contingent screening, where only a certain proportion of pregnant women determined by the degree of risk receive NIPT, may be feasible" [77].

Some authors argued that public health care systems need to consider the cost implications of offering tests that will not change pregnancy management [19] and the impact of implementing testing "for information only" (with no intention to terminate) [34,51]. Such debates are clearly ethically sensitive because they imply a certain interference with women's reproductive autonomy and free choice regarding why they want information and how they will manage their pregnancy based on a (potentially) positive result from the test. Thus, important questions remain to be answered about whether public funding of NIPT represents a good use of scarce resources in a public healthcare system [54].

The NIPT ELSI literature has also argued that decision-making by governmental agencies, public and private insurers, research institutions and biotechnology companies regarding investment in research and coverage of NIPT should take into consideration the values, opinions and preferences of various stakeholders (e.g., families, healthcare providers, professional societies, and representatives of civil society such as community activists) [19]. It has been suggested that guidelines, policies and regulations be developed by professional societies, health agencies and the government to promote an ethically sound implementation of NIPT [50], one that is not governed merely by market pressures [71].

\section{Discussion}

The ELSI literature regarding NIPT discusses benefits and concerns that are similar to those introduced by other prenatal tests, such as amniocentesis and serum screening. Challenges regarding informed consent, informed decision-making, potential routinization, trivialization of termination, lowering the threshold of testing, genetic counselling, eugenics, discrimination against people with disabilities and equity of access to the test $[44,45]$ are not novel. Yet, NIPT seems to exacerbate some of these issues. While the unique features of the test (safety, ease and earlier timing) potentially represent important clinical benefits, the large scale introduction of NIPT might promote certain negative effects of routinization by increasing test uptake and therefore termination rates [5,63], which might in turn lead to discrimination and stigmatisation of people living with disabilities and their families.

Moreover, as the technology advances, we observed that the ELSI debate has been influenced by the shift in NIPT's clinical status from being perceived as a 'diagnostic' test (NIPD) to being introduced as a 'screening' test (NIPT/NIPS). Whereas the abovementioned concerns were very prevalent in the "NIPD-days" - and are still tackled in the current literature on NIPT - other concerns now seem to garner more attention with the widespread introduction of NIPT, such as the equity of access that emerged as a frequent challenge for an appropriate clinical introduction of the test $[5,7,80]$. 
In the literature published between 2007 and 2015, we observed that the debate around NIPT generally moved from being mostly conceptual to more empirical. This move might be explained in various ways: the conceptual work may have informed the design of the empirical studies; the empirical work appeared later on, due to the time it takes to set up and conduct empirical projects; and funding opportunities for empirical work may have been delayed based on the ongoing recognition and presence of NIPT in clinical practice. ${ }^{3}$ Moreover, empirical studies (using qualitative or quantitative methods) were needed to assess views, preferences, attitudes and needs of pregnant women, partners and health professionals and to inform the conceptual ELSI debate surrounding this recent technology. Therefore, such studies were and are still performed in many countries, such as the Netherlands [20], the US [21], the UK [27,34], Hong Kong [42], and Japan [62]. Results showed overall positive attitudes regarding NIPT [20,25,27,81], with women and partners valuing mostly the safety of the test and health professionals its accuracy [25,34]. They also demonstrated the important contribution of the empirical work to the normative debate around NIPT. For instance, empirical studies provided evidence of the concerns that were raised in the conceptual literature, confirming the early concerns about the challenges to meet an appropriate level of informed consent in the context of NIPT [28,43]. Empirical studies can also inform the development of public policies and guide the development of an infrastructure for NIPT's clinical implementation [7].

It is expected that in the coming years, NIPT will be used to screen for a wide-range of fetal conditions, including childhood disorders and late-onset diseases. Inevitably, this raises questions regarding the expansion in scope of prenatal testing associated with the rights of the future child [55]. What conditions should be tested? What information can be harmful to the child? And who decides? These questions need further research and debate. As NIPT implementation expands, challenges should be debated by all stakeholders - including professional societies, health ministries, public and private insurance providers, patients and clinicians - in order to guide the development of NIPT practice guidelines and policy and so ensure that it is used in an ethically and socially acceptable manner.

\section{List of References}

1. Lo YM, Corbetta N, Chamberlain PF, Rai V, Sargent IL, Redman CW, et al. Presence of fetal DNA in maternal plasma and serum. Lancet. 1997;350(9076):485-7.

2. Palomaki GE, Deciu C, Kloza EM, Lambert-Messerlian GM, Haddow JE, Neveux LM, et al. DNA sequencing of maternal plasma reliably identifies trisomy 18 and trisomy 13 as well as Down syndrome: an international collaborative study. Genetics in Medicine. 2012;14(3):296305.

3. Bianchi DW, Platt LD, Goldberg JD, Abuhamad AZ, Sehnert AJ, Rava RP. Genome-wide fetal aneuploidy detection by maternal plasma DNA sequencing. Obstetrics and Gynecology. 2012;119(5):890-901.

4. Salomon LJ, Alfirevic Z, Audibert F, Kagan KO, Paladini D, Yeo G, et al. ISUOG consensus statement on the impact of non-invasive prenatal testing (NIPT) on prenatal ultrasound practice. Ultrasound in Obstetrics \& Gynecology. 2014;44(1):122-3.

5. Allyse M, Minear MA, Berson E, Sridhar S, Rote M, Hung A, et al. Non-invasive prenatal testing: a review of international implementation and challenges. International Journal of Women's Health. 2015;7:113-26.

6. Pagon RA, Adam MP, Ardinger HH, et al., editors. GeneReviews. Illustrated Glossary. Seattle (WA): University of Washington, Seattle; 1993-2016.

7. Dondorp W, de Wert G, Bombard Y, Bianchi DW, Bergmann C, Borry P, et al. Non-invasive prenatal testing for aneuploidy and beyond: challenges of responsible innovation in prenatal screening. European Journal of Human Genetics. 2015;23(11):1438-50.

\footnotetext{
${ }^{3}$ The authors thank Dr. Zuzana Deans for these suggestions.
} 
8. Norton ME, Rose NC, Benn P. Noninvasive prenatal testing for fetal aneuploidy: clinical assessment and a plea for restraint. Obstetrics and Gynecology. 2013;121(4):847-50.

9. Wilson KL, Czerwinski JL, Hoskovec JM, Noblin SJ, Sullivan CM, Harbison A, et al. NSGC practice guideline: prenatal screening and diagnostic testing options for chromosome aneuploidy. Journal of Genetic Counseling. 2013;22(1):4-15.

10. Gregg AR, Gross SJ, Best RG, Monaghan KG, Bajaj K, Skotko BG, et al. ACMG statement on noninvasive prenatal screening for fetal aneuploidy. Genetics in Medicine. 2013;15(5):395-8.

11. Committee Opinion No. 545: Noninvasive prenatal testing for fetal aneuploidy. Obstetrics and Gynecology. 2012;120(6):1532-4.

12. Hudecova I, Sahota D, Heung MM, Jin Y, Lee WS, Leung TY, et al. Maternal plasma fetal DNA fractions in pregnancies with low and high risks for fetal chromosomal aneuploidies. PLoS ONE. 2014;9(2):e88484.

13. Lench N, Barrett A, Fielding S, McKay F, Hill M, Jenkins L, et al. The clinical implementation of non-invasive prenatal diagnosis for single gene disorders: Challenges and progress made. Prenatal Diagnosis. 2013;33(6) :555-62.

14. Lo YM, Chan KC, Sun H, Chen EZ, Jiang P, Lun FM, et al. Maternal plasma DNA sequencing reveals the genome-wide genetic and mutational profile of the fetus. Science Translational Medicine. 2010;2(61):61ra91.

15. Kitzman JO, Snyder Mw Fau - Ventura M, Ventura M Fau - Lewis AP, Lewis Ap Fau - Qiu R, Qiu R Fau - Simmons LE, Simmons Le Fau - Gammill HS, et al. Noninvasive whole-genome sequencing of a human fetus. Science Translational Medicine. 2012;4(137):137ra76

16. Morain S, Greene MF, Mello MM. A new era in noninvasive prenatal testing. The New England Journal of Medicine. 2013;369(6):499-501.

17. Pollack A. Conflict potential seen in genetic counselors. The New York Times. 2012 July 13.

18. Benn P, Chapman AR, Erickson K, Defrancesco MS, Wilkins-Haug L, Egan JF, et al. Obstetricians' and gynecologists' practice and opinions of expanded carrier testing and noninvasive prenatal testing. Prenatal Diagnosis. 2014;34(2):145-52.

19. Sayres LC, Allyse M, Cho MK. Integrating stakeholder perspectives into the translation of cellfree fetal DNA testing for aneuploidy. Genome Medicine. 2012;4:49.

20. van Schendel RV, Kleinveld JH, Dondorp WJ, Pajkrt E, Timmermans DR, Holtkamp KC, et al. Attitudes of pregnant women and male partners towards non-invasive prenatal testing and widening the scope of prenatal screening. European Journal of Human Genetics. 2014;22(12):1345-50.

21. Horsting JM, Dlouhy SR, Hanson K, Quaid K, Bai S, Hines KA. Genetic counselors' experience with cell-free fetal dna testing as a prenatal screening option for aneuploidy. Journal of Genetic Counseling. 2014;23(3):377-400.

22. Kellogg G, Slattery L, Hudgins L, Ormond K. Attitudes of mothers of children with Down syndrome towards noninvasive prenatal testing. Journal of Genetic Counseling. 2014;23(5):805-13.

23. Shields AD, Vidosh JD. Average-risk pregnant patient perspectives on noninvasive prenatal testing. Obstetrics and Gynecology. 2014;123 Suppl 1:79S-80S.

24. Kaposy C. A disability critique of the new prenatal test for Down syndrome. Kennedy Institute of Ethics Journal. 2013;23(4):299-324.

25. Hill M, Fisher J, Chitty LS, Morris S. Women's and health professionals' preferences for prenatal tests for Down syndrome: a discrete choice experiment to contrast noninvasive prenatal diagnosis with current invasive tests. Genetics in Medicine. 2012;14(11):905-13.

26. Hill M, Compton C, Karunaratna M, Lewis C, Chitty L. Client views and attitudes to noninvasive prenatal diagnosis for sickle cell disease, thalassaemia and cystic fibrosis. Journal of Genetic Counseling. 2014;23(6):1012-21.

27. Lewis C, Silcock C, Chitty LS. Non-invasive prenatal testing for Down's syndrome: pregnant women's views and likely uptake. Public Health Genomics. 2013;16(5):223-32.

28. Silcock C, Liao L-M, Hill M, Chitty LS. Will the introduction of non-invasive prenatal testing for Down's syndrome undermine informed choice? Health Expectations. 2015;18(5):1658-71. 
29. Benn PA, Chapman AR. Ethical challenges in providing noninvasive prenatal diagnosis. Current Opinion in Obstetrics \& Gynecology. 2010;22(2):128-34.

30. Hall A, Bostanci A, Wright CF. Non-invasive prenatal diagnosis using cell-free fetal DNA technology: applications and implications. Public Health Genomics. 2010;13(4):246-55.

31. Vanstone M, Yacoub K, Giacomini M, Hulan D, McDonald S. Women's experiences of publicly funded non-invasive prenatal testing in Ontario, Canada: Considerations for health technology policy-making. Qualitative Health Research. 2015;25(8):1069-84.

32. Dixon-Woods M, Cavers D, Agarwal S, Annandale E, Arthur A, Harvey J, et al. Conducting a critical interpretive synthesis of the literature on access to healthcare by vulnerable groups. BMC Medical Research Methodology. 2006;6:35.

33. Deans Z, Newson AJ. Ethical considerations for choosing between possible models for using NIPD for aneuploidy detection. Journal of Medical Ethics. 2012;38(10):614-8.

34. Hill M, Karunaratna M, Lewis C, Forya F, Chitty L. Views and preferences for the implementation of non-invasive prenatal diagnosis for single gene disorders from health professionals in the united kingdom. American Journal of Medical Genetics Part A. 2013;161(7):1612-18.

35. Wright C. Cell-free fetal nucleic acids for non-invasive prenatal diagnosis. PHG Foundation, 2009.

36. Hewison J. Psychological aspects of individualized choice and reproductive autonomy in prenatal screening. Bioethics. 2015;29(1):9-18.

37. Wright CF, Burton $\mathrm{H}$. The use of cell-free fetal nucleic acids in maternal blood for non-invasive prenatal diagnosis. Human reproduction update. 2009;15(1):139-51.

38. Seavilleklein V. Challenging the rhetoric of choice in prenatal screening. Bioethics. 2009;23(1):68-77.

39. Benn P, Cuckle H, Pergament E. Non-invasive prenatal testing for aneuploidy - current status and future prospects. Ultrasound in Obstetrics \& Gynecology. 2013;42(1):15-33.

40. Davis DS. Opportunistic testing: the death of informed consent? Health Matrix Cleveland. 2013;23(1):35-54.

41. Tischler R, Hudgins L, Blumenfeld YJ, Greely HT, Ormond KE. Noninvasive prenatal diagnosis: pregnant women's interest and expected uptake. Prenatal Diagnosis. 2011;31(13):1292-9.

42. Yi H, Hallowell N, Griffiths S, Leung TY. Motivations for undertaking dna sequencing-based non-invasive prenatal testing for fetal aneuploidy: a qualitative study with early adopter patients in Hong Kong. PloS One. 2013;8(11):e81794.

43. van den Heuvel A, Chitty L, Dormandy E, Newson A, Deans Z, Attwood S, et al. Will the introduction of non-invasive prenatal diagnostic testing erode informed choices? An experimental study of health care professionals. Patient Education and Counseling. 2010;78(1):24-8.

44. Benn Pa, Chapman AR. Practical and ethical considerations of noninvasive prenatal diagnosis. Journal of American Medical Association. 2009;301(20):2154-6.

45. King JS. And genetic testing for all... The coming revolution in non-invasive prenatal genetic testing. Rutgers Law Journal. 2011;42:599-819.

46. Willems PJ, Dierickx H, Vandenakker E, Bekedam D, Segers N, Deboulle K, et al. The first 3,000 Non-Invasive Prenatal Tests (NIPT) with the Harmony test in Belgium and the Netherlands. Facts, Views \& Vision in ObGyn. 2014;6(1):7-12.

47. Research TM. Non-Invasive Prenatal Testing (NIPT) Market: (MaterniT21 PLUS, verifi, Harmony, Panorama, NIFTY, PrenaTest and BambniTest) Global Industry Analysis, Size, Share, Growth, Trends and Forecast, 2013 - 2019.

48. Dondorp W, de Wert G, Bombard Y, Bianchi DW, Bergmann C, Borry P, et al. Non-invasive prenatal testing for aneuploidy and beyond: challenges of responsible innovation in prenatal screening. Summary and recommendations. European Journal of Human Genetics. $2015 \mathrm{Apr}$ 1. doi: 10.1038/ejhg.2015.56 
49. Minear MA, Alessi S, Allyse M, Michie M, Chandrasekharan S. Noninvasive prenatal genetic testing: current and emerging ethical, legal, and social issues. Annual Review of Genomics and Human Genetics. 2015;16:369-98.

50. Allyse MA, Sayres LC, Havard M, King JS, Greely HT, Hudgins L, et al. Best ethical practices for clinicians and laboratories in the provision of non-invasive prenatal testing. Prenatal Diagnosis. 2013;33(7):656-61.

51. Deans Z, Hill M, Chitty LS, Lewis C. Non-invasive prenatal testing for single gene disorders: exploring the ethics. European Journal of Human Genetics. 2013;21(7):713-8.

52. Hill M, Barrett AN, White H, Chitty LS. Uses of cell free fetal DNA in maternal circulation. Best Practice \& Research Clinical Obstetrics \& Gynaecology. 2012;26(5):639-54.

53. de Jong A, Dondorp WJ, de Die-Smulders CE, Frints SG, de Wert GM. Non-invasive prenatal testing: ethical issues explored. European Journal of Human Genetics. 2010;18(3):272-7.

54. Newson AJ. Ethical aspects arising from non-invasive fetal diagnosis. Seminars in Fetal \& Neonatal Medicine. 2008;13(2):103-8.

55. Deans Z, Clarke AJ, Newson AJ. For your interest? The ethical acceptability of using noninvasive prenatal testing to test 'purely for information'. Bioethics. 2015;29(1):19-25.

56. Menezes M, Meagher S, Costa Fda S. Ethical considerations when offering noninvasive prenatal testing. Revista Brasileira de Ginecologia e Obstetricia. 2013;35(5):195-8.

57. Verweij EJ, Oepkes D, de Boer MA. Changing attitudes towards termination of pregnancy for trisomy 21 with non-invasive prenatal trisomy testing: a population-based study in Dutch pregnant women. Prenatal Diagnosis. 2013;33(4):397-9.

58. Yagel S. Non-invasive prenatal testing: more questions than answers. Ultrasound in Obstetrics \& Gynecology. 2013;42(4):369-72.

59. Henry T. Greely JSK. The coming revolution in prenatal genetic testing. Professional Ethics Report. 2010;23(2):3.

60. Skirton $\mathrm{H}$, Patch $\mathrm{C}$. Factors affecting the clinical use of non-invasive prenatal testing: a mixed methods systematic review. Prenatal Diagnosis. 2013;33(6):532-41.

61. Lewis C, Hill M, Skirton H, Chitty LS. Fetal sex determination using cell-free fetal DNA: service users' experiences of and preferences for service delivery. Prenatal Diagnosis. 2012;32(8):735-41.

62. Yotsumoto J, Sekizawa A, Koide K, Purwosunu Y, Ichizuka K, Matsuoka R, et al. Attitudes toward non-invasive prenatal diagnosis among pregnant women and health professionals in Japan. Prenatal Diagnosis. 2012;32(7):674-9.

63. King JS. Not this child: constitutional questions in regulating noninvasive prenatal genetic diagnosis and selective abortion. UCLA Law Review. 2012;60:2.

64. Wilkinson S. Prenatal screening, reproductive choice, and public health. Bioethics. 2015;29(1):26-35.

65. Haymon L. Non Invasive Prenatal Genetic Diagnosis (NIPD). Council for Responsible Genetics, 2011.

66. Parens E, Asch A. Disability rights critique of prenatal genetic testing: reflections and recommendations. Mental Retardation and Developmental Disabilities Research Reviews. 2003;9(1):40-7.

67. Kent A. Non-invasive prenatal diagnosis: public and patient perceptions. Seminars in Fetal \& Neonatal Medicine. 2008;13(2):109-12.

68. Chachkin CJ. What potent blood: non-invasive prenatal genetic diagnosis and the transformation of modern prenatal care. American Journal of Law \& Medicine. 2007;33(1):953.

69. Ma Y, Gong H, Wen Y. Nucleic acid-based non-invasive prenatal diagnosis of genetic skin diseases: are we ready? Experimental Dermatology. 2013;22(6):392-5.

70. Farrimond HR, Kelly SE. Public viewpoints on new non-invasive prenatal genetic tests. Public Understanding of Science. 2013;23(6):730-44.

71. Agarwal A, Sayres LC, Cho MK, Cook-Deegan R, Chandrasekharan S. Commercial landscape of noninvasive prenatal testing in the United States. Prenatal Diagnosis. 2013;33(6):521-31. 
72. Fikes BJ. Illumina, Sequenom settle patent dispute. San Diego Union-Tribune. 2014; Dec. 3.

73. Twiss $P$, Hill M, Daley R, Chitty LS. Non-invasive prenatal testing for Down syndrome. Seminars in Fetal \& Neonatal Medicine. 2014;19(1):9-14.

74. Vahanian SA, Allaf MB, Yeh C, Chavez MR, Kinzler WL, Vintzileos AM. Patient Acceptance of Non-invasive Testing for Fetal Aneuploidy via Cell-free Fetal DNA. The Journal of MaternalFetal \& Neonatal Medicine. 2014;27(1):106-9.

75. Ventura W, Nazario-Redondo C, Sekizawa A. Non-invasive prenatal diagnosis from the perspective of a low-resource country. International Journal of Gynaecology and Obstetrics. 2013;122(3):270-3.

76. de Jong A, Dondorp WJ, Frints SG, de Die-Smulders CE, de Wert GM. Advances in prenatal screening: the ethical dimension. Nature Reviews Genetics. 2011;12(9):657-63.

77. Non-invasive Prenatal Testing: A Review of the Cost Effectiveness and Guidelines. Ottawa ON: 2014 Canadian Agency for Drugs and Technologies in Health. CADTH Rapid Response Reports; 2014 Feb 10.

78. Neyt M, Hulstaert F, Gyselaers W. Introducing the non-invasive prenatal test for trisomy 21 in Belgium: a cost-consequences analysis. BMJ Open. 2014;4(11):e005922.

79. Munthe $C$. A new ethical landscape of prenatal testing: individualizing choice to serve autonomy and promote public health: a radical proposal. Bioethics. 2015;29(1):36-45.

80. Chandrasekharan S, Minear MA, Hung A, Allyse M. Noninvasive prenatal testing goes global. Science Translational Medecine. 2014;6(231):231fs15.

81. Verweij EJ, Oepkes D, de Vries M, van den Akker ME, van den Akker ES, de Boer MA. Noninvasive prenatal screening for trisomy 21: What women want and are willing to pay. Patient Education and Counseling. 2013;93(3):641-5. 